\title{
Water Pipe Leakage Detector Using a Pressure Transmitter Sensor with a Remote Distance Smartphone Display
}

\author{
Bisman Perangin-angin ${ }^{1 *}$ and Aryanti Agustina Br Sitepu ${ }^{2}$ \\ 1,2 Department of Physics, Faculty of Mathematics and Natural Science, Universitas Sumatera Utara \\ 20155, Indonesia
}

\begin{abstract}
This research aimed to design the air pipe leak detection using a pressure transmitter sensor with a smartphone as a display. The research produced a method that can be relied upon by pipe leaks quickly and accurately. The method was carried out by using two flowmeter sensors that are placed before and after the pipe leak point to record data on the difference between intake and exit air flow $(\Delta \mathrm{Q})$. The resulting data was transmitted to the computer using a TCP/IP-based network. The results obtained show that the smaller the difference in the flow of air into and out $(\Delta \mathrm{Q})$, the farther the pipe leak is $(\mathrm{X})$.
\end{abstract}

Keyword: pressure transmitter sensor, ATMega8535 microcontroller, IOT.

Received 5 February 2021 | Revised [19 February 2021] | Accepted [25 February 2021]

\section{Introduction}

In the era of technological advances, it is not impossible for a pipe leak detection system to be carried out quickly and automatically. This is supported by physical theories and related studies that have been carried out [1]. Mathematical modeling and experimental testing to determine the location of pipe leaks [2]. Some research conducted on monitoring and detecting the location of clean water pipeline leaks based on the flow of water [3-4].

Physical theory regarding the continuity equation for incompressible flow, if there is no accumulation of addition or reduction of fluid in a volume, the flow rate of fluid entering the volume must be equal to the flow rate out of the volume [5]. Pressure drop caused by pipe leaks [6]. In addition, the pressure also decreases as the height increases [7]. In designing this tool the ATMega microcontroller will be the controller of each component [8] and ATMega is programmed in computer language [9].

*Corresponding author at: Jl. Bioteknologi No.1 Kampus USU, Medan, Indonesia, 20155

E-mail address: bisman@usu.ac.id 
The microcontroller functions as the control center of the entire system being made. The components of the circuit are the ATMega8535 Microcontroller IC [10]. Setting the time for each pressure ratio is very important as a constant value [11]. AVR architecture consists of two main memories, namely data memory and program memory [12].

The working principle of a differential pressure transmitter is to measure the pressure at two points [13]. The size of the pipe diameter will affect the pressure [14]. Several supporting components will assist in the design of a circuit [15]. A sensor that is useful for measuring the amount of pressure will provide an output in the form of an electric signal which is then sent to the controller by the transmitter [16]. MCU V3 node is an interface module that functions as an intermediary for sending and receiving data from the internet network [17]. The pressure gradient technique (flow measurement) basically requires the introduction of flow resistance [18-20].

\section{Methods}

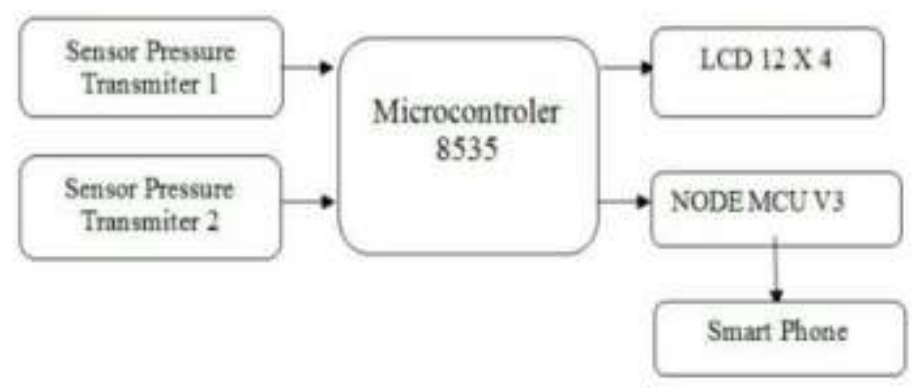

Figure 1. Block Diagram

The block diagram of the device is given in Figure 1 and the flowchart is depicted in Figure 2. In brief, water flows in the pipe and will produce a pressure, then the pressure will be read by the pressure transmitter sensor. when a leak occurs, the pressure received at the beginning will be left behind than the second sensor which is positioned at a certain distance. By using certain applications we can find out that there is a water pipe leak which will then be displayed on the LCD display and a smartphone has a leak. 


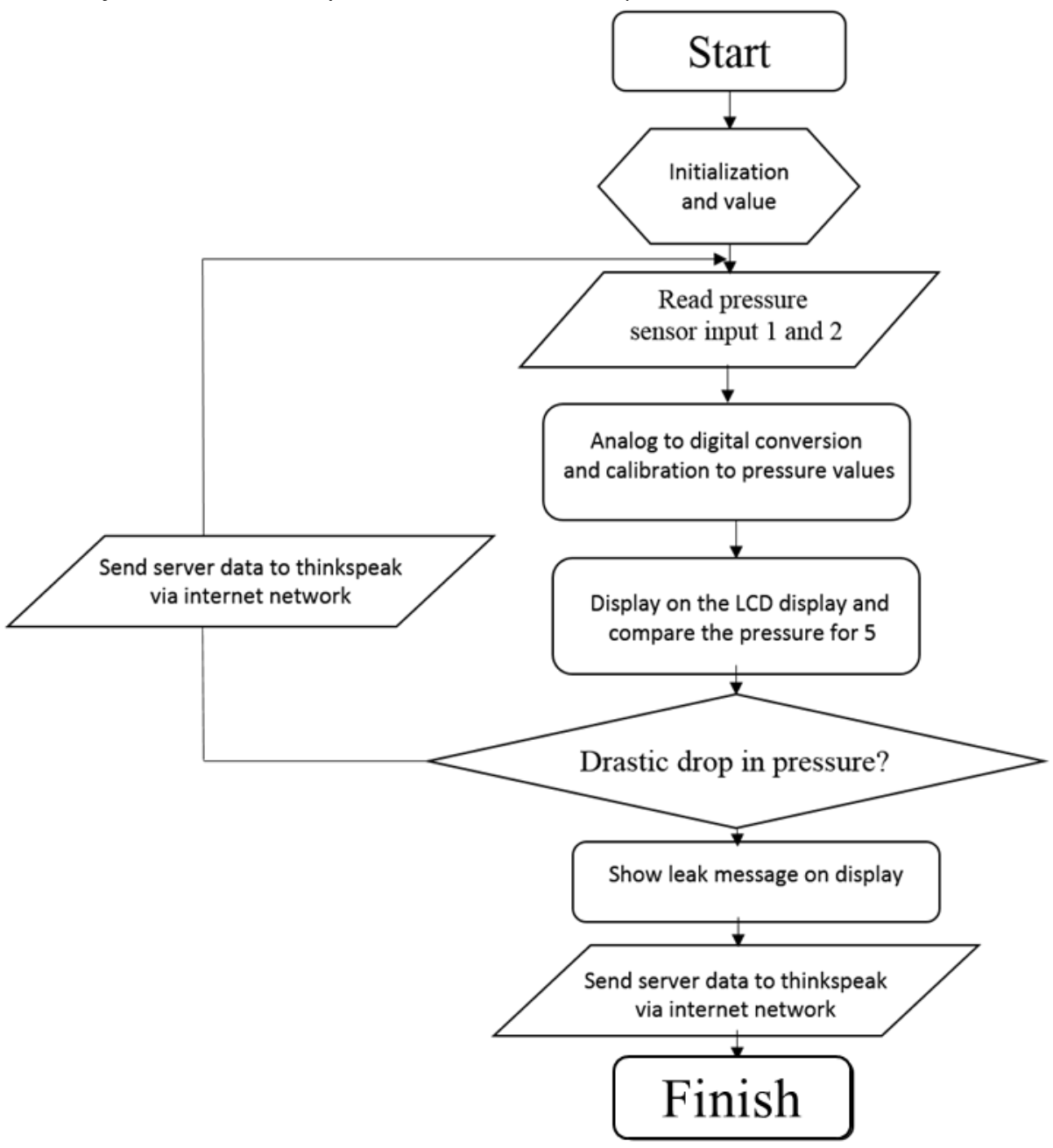

Figure 2. Flowchart of the Pipe Leak Detection System

The sensor used is an analog output pressure sensor. According to the sensor data sheet the sensor output voltage is from 0.5 to $4.5 \mathrm{~V}$ for a pressure of 0 to $1.2 \mathrm{MPa}$. The sensor is calibrated by the microcontroller from voltage to pressure in $\mathrm{kPa}$ units which is displayed on the LCD display. Testing is done by gradually applying water pressure to the sensor, then measuring the voltage and observing the display of the microcontroller program. The following are the results of tests carried out on the $1 / 4 \mathrm{G}$ pressure transmitter sensor.

\section{Result and Discussion}

The results of no leakage and with leakage experiments are given in Table 1 and Table 2.

Table 1. No Leakage Experiments

\begin{tabular}{cccc}
\hline Sensor & Pressure I (Kpa) & Pressure II (Kpa) & Pressure III(Kpa) \\
\hline Sensor 1 & 115 & 115 & 114 \\
Sensor 2 & 114 & 115 & 113 \\
\hline
\end{tabular}


Table 2. Experiments with Leaks

\begin{tabular}{ccc}
\hline $\begin{array}{c}\text { Leak distance } \\
(\mathbf{c m})\end{array}$ & $\begin{array}{c}\text { Pressure on Sensor I } \\
(\mathbf{K P a})\end{array}$ & $\begin{array}{c}\text { Pressure on Sensor II } \\
(\mathbf{K P a})\end{array}$ \\
\hline \multirow{3}{*}{50} & 43 & 35 \\
& 43 & 34 \\
& 44 & 35 \\
& 41 & 35 \\
200 & 41 & 34 \\
& 42 & 37 \\
& 40 & 31 \\
400 & 41 & 33 \\
& 40 & 33 \\
& 40 & 31 \\
800 & 40 & 30 \\
& 41 & 33 \\
& 40 & 31 \\
\multirow{2}{*}{1100} & 41 & 32 \\
& 40 & 30 \\
\hline
\end{tabular}

The pressure gradient (flow measurement) technique basically requires the introduction of flow resistance. Measuring the pressure gradient across a known resistor makes it possible to calculate the flow rate. This concept is analogous to Ohm's law: the voltage (pressure) across the resistor remains proportional to the current (flow). As the moving mass enters an area of higher resistance, its speed increases in proportion to the increase in resistance (equation 2).

$$
v_{1 a}=v_{2 a} \mathrm{R}
$$

The Bernoulli equation defines differential pressure as in equation (2)

$$
\Delta p=p 1-p 2=\rho / 2\left(v_{2 a}^{2}-v_{1 a}^{2}\right)=k \frac{\rho}{2} v_{2 a}^{2}\left(1-R^{2}\right)
$$

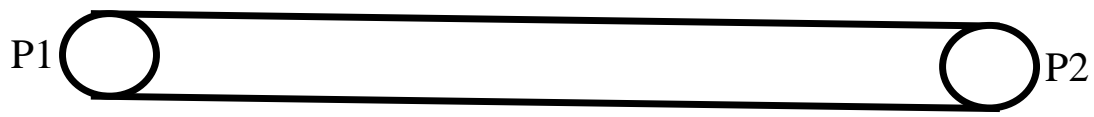


P1 > P2, based on the Bernoulli Equation that when a leak occurs, the P2 and R values will decrease. Testing is done to determine the function of the whole system whether it is in accordance with the objectives or not. After all components are installed in the system, testing can be carried out. Starting from the activation of the power supply, the display will display text, namely the name of the device or system. After that the program will begin to read the pressure on the sensor, namely sensor 1, and display it on the display. At that time it is worth 0 because the pump has not started.

The next step is to turn on the pump by providing an electric current to the pump. The display shows an increase in pressure on sensor 1 but on sensor 2 it is still 0 because at the end of the pipe where sensor 2 is installed, water flows smoothly and is not obstructed. Furthermore, the tap at the output end of the pipe is closed, at this time the pressure on sensor 2 immediately rises to a maximum of $128 \mathrm{KPa}$. The next stage, the water tap is closed initially and the pump is turned off so that the pressure will be the same at the beginning and end of the pipe. The pressure will be the same and remain unchanged for both sensors. After waiting for a while the system will display the text "no leak detected" on the display. Leak simulation is done by opening one of the holes that have been made between the pipes. You will see a significant pressure drop on the display and a few moments later the text "Pipe leak detected" will appear. Until this stage, it can be stated that the tool designed has worked according to the goals and expectations, which is to detect leaks in the pipe.

The test was continued by testing the monitoring process via the internet. The server used for data transfer is Thingspeak. The Thingspeak application requires an account to log in to a user where an account has been previously created or registered. The login process is carried out online and after logging in to the user account, click on the name of the project that has been created on thingspeak. Ensure that the tool has been connected to the specified wifi hotspot so that it can send data to thingspeak. When the connection is successful the display in the form of pressure sensor display will appear in accordance with the value displayed on the LCD display. Thus the pressure monitoring process has worked well and the system has been successfully established.

\section{Conclusion}

A leak detector in a pipe can work well because it can detect leaks in water pipes. In Bernoulli's equation, it can be concluded that when there is a leak, the pressure and resistance will decrease. The basic principle of leak detection is the loss of pressure on one of the sensors at a fast time, the use of the pressure transmitter sensor changes it from a sensor to a signal that can be decoded by the controller. 
[1] B. Santoso, "Deteksi Kebocoran Pipa Pada Aliran Dua Fase Plug Menggunakan Analisis Fluktuasi Beda Tekanan", Jurnal Energi dan Manufaktur, 2013.

[2] A. H. A. Baghdadi, and h. A. Mansy, "A Mathematical Model For Leak Location In Pipelines", Application Mathematical Modeling, 1988.

[3] R. S. Rijal, "Rancang Bangun Alat Deteksi Kebocoran Pipa Distribusi Air Berbasis Sensor Tekanan Dan Mikrokontroler", Doctoral dissertation, Institut Teknologi Sepuluh Nopember, 2018.

[4] H. I. Kirom, S. Sumardi, and S. Sudjadi, "Sistem Monitoring Kebocoran Gas LPG (liquefied Petroleum Gas) Pada Smart Building Berbasis TCP/IP", Transient: Jurnal Ilmiah Teknik Elektro, vol. 2, no. 2, pp.329-336, 2013.

[5] B. Munson, and D. Young, Mekanika Fluida Edisi Keempat. Jakarta: Erlangga, 2004.

[6] A. M. Sadeghioon, N. Metje, D. N. Chapman, and C. J. Anthony, "SmartPipes: Smart Wireless Sensor Networks for Leak Detection in Water Pipelines", Journal of Sensor and Actuator Networks, 2014.

[7] R. A. Serway, and J. W. Jewett, Fisika Untuk Sains dan Teknik, Jakarta, 2009.

[8] R. H. Zain, "Sistem Keamanan Ruangan Menggunakan Sensor Passive Infra Red (PIR) Dilengkapi Kontrol Penerangan Pada Ruangan Berbasis Mikrokontroler ATmega8535 Dan Real Time Clock DS1307", Jurnal Teknologi Informasi dan Pendidikan, 2013.

[9] A. C. Bejo, AVR Rahasia Kemudahan Bahasa C dalam Mikrokontroler ATmega8535. Yogyakarta: Graha Ilmu, 2008.

[10] Atmel Co, "ATmega8535," Atmel Co., Ltd, All Rights Reserved, 2010.

[11] H. H. Rachmat, A. N. Indrawan, dan N. Syafitri, Pengembangan Sistem Remote Control Untuk Setting Waktu Pada Sistem Automatic Time Switch (ATS) Berbasis Real Time Clock (RTC) DS1307 Untuk Saklar Lampu. Jurnal Rekayasa, 2011.

[12] H. Andrianto, Pemrograman Mikrokontroler AVR ATmega 8535 Menggunakan Bahasa C (CodeVisionAVR), Bandung, Informatika Bandung, 2013.

[13] M. Yusro, and Aodah, Sensor transduser, Jakarta: Erlangga, 2019.

[14] D. Biksono, "Karakteristik dan Visualisasi Aliran Dua Fasa Pada Pipa Spiral", Jurnal Teknik Mesin, 2006.

[15] S. Wasito, Kumpulan Data Penting Komponen Elektronika, Jakarta: PT Multimedia, 1986.

[16] F. Jacob, Handbook of Modern Sensor, New York. Inc, 1996.

[17] R. B. Widodo, Embedded System Menggunakan Mikrokontroler Dan Pemrograman C, Yogyakarta: Andi, 2009.

[18] D. Suroso, Persamaan Bernollie, Jakarta, 2018.

[19] A. Gradha, Instrumentasi Pressure Transmitter, Yogyakarta, 2017.

[20] M. M. Gamboa-Medina, and L. F. R. Reis, "Sampling Design For Leak Detection In Water Distribution Networks", Procedia Engineering, 2017. 